\title{
CONTEMPORARY SOCIAL-GEOGRAPHIC PROCESSES IN REGIONAL DEVELOPMENT OF POTKOZARJE
}

DOI: http://dx.doi.org/10.18509/GBP.2018.64

UDC: 528.94:502.11(497.6)

\author{
Tanja Mišlicki Tomić \\ Aleksandra Petrašević \\ University of Banja Luka, Republic of Srpska-Bosnia and Herzegovina
}

\begin{abstract}
Potkozarje is conditionally differentiated regional system in the northwestern part of the Republic of Srpska, which, in administrative and territorial terms, belongs to communities of different territorial organization and status - City of Banja Luka and City of Prijedor and municipalities of Novi Grad, Kostajnica, Kozarska Dubica, Gradiška and Laktaši.

Potkozarje, with regard to the physiognomy of space and development processes, has a complex settlement function. Development centers from the environment have a crucial impact on the development processes in the region. Development impacts changed demographic, functional and spatial structure and a new system of spatial relations was created. The centers in the region have become the zones of extreme concentration of population and functions, thus the region faced many destructive processes and problems of unequal regional development.

The aim of this paper is to explore the dynamics of structural changes and to point out the key problems of unequal regional development, as consequences of economic, social and political factors, as well as of diversity of natural basis.
\end{abstract}

Key words: structural changes, spatial differentiation, unequal regional development, Potkozarje

\section{INTRODUCTION}

Natural physiognomy, functional connection and processes in social and geographical development make the basic criteria on which the regional differentiation of Potkozarje is based. [1]

Acknowledging the mentioned criteria, the term Potkozarje means relatively differentiated spatial unit, in the mountain system of Kozara, in the northwestern part of the Republic of Srpska.

The area of Potkozarje, in the mountain system of Kozara, is $1848,3 \mathrm{~km}^{2}$ or $7,3 \%$ of the total territory of the Republic of Srpska, where, according to the population census for the year 2013, there is 91097 residents or about $7 \%$ of population of the Republic of Srpska.

Population density of Potkozarje is 49 residents $/ \mathrm{km}^{2}$, which, in relation to population density of the Republic of Srpska which is 46 residents $/ \mathrm{km}^{2}$, makes it relatively wellpopulated region.

Natural physiognomy of Potkozarje is reflected in the relative homogeneity of the elements of the natural environment, especially of relief and eco-vegetation systems. 
Based on the relative homogeneity of the mentioned natural characteristics, the upper limit of Potkozarje is determined. It is consisted of isohypse of 500 meters height above see level, at the same time it is the upper limit of population

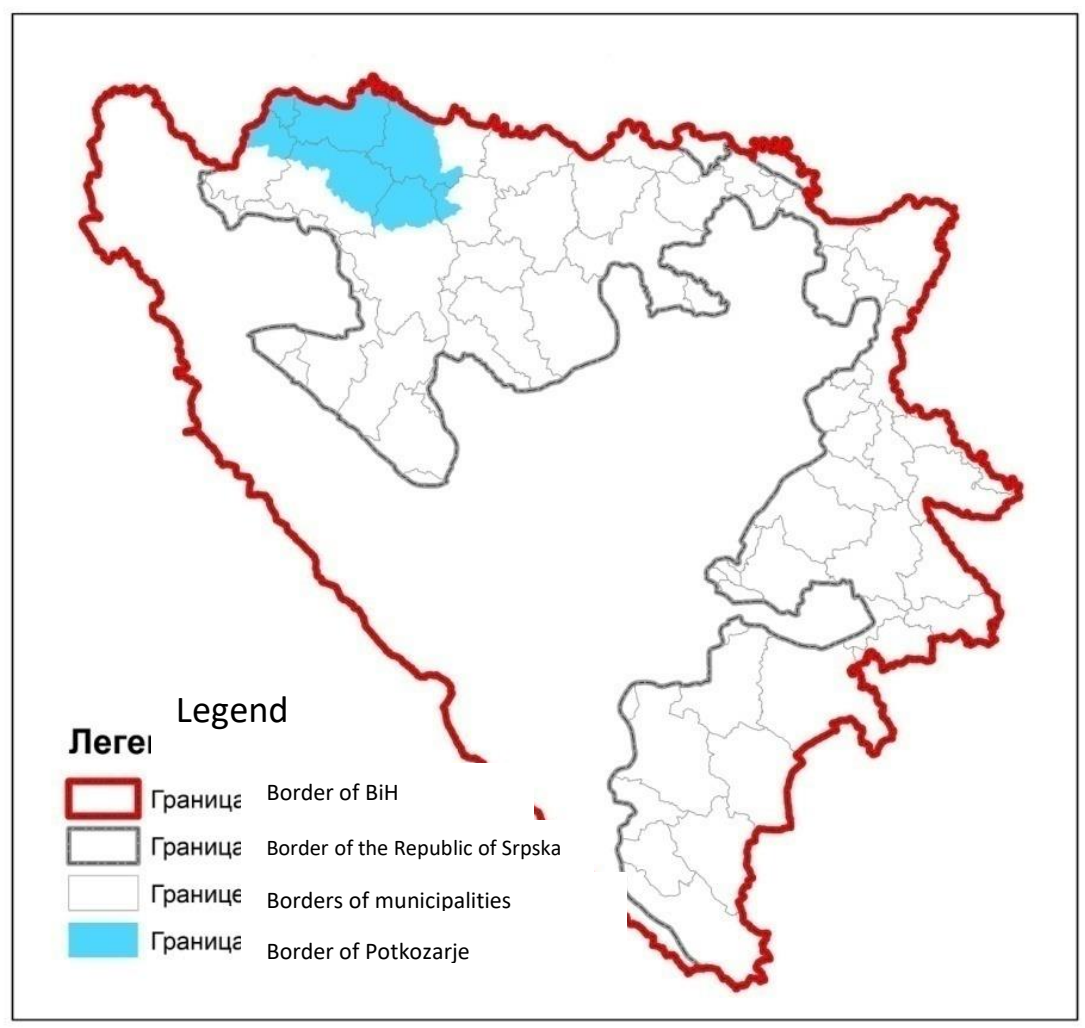

Figure 1. Position of Potkozarje in the Republic of Srpska

Potkozarje leans on, with its northwestern base of Dubica lowland and western slopes of Veliko Pastirevo and Malo Pastirevo, the right bank of the Una River, the border river with the Republic of Croatia. With its north base Prosara, it leans on the right bank of the rivers Sava and Una. In the northeast, by the rivers Jablanica, Vrbaška and Lubinja, more precisely by alluvial plain developed from torrential inundated drifts from Kozara and Prosara, it delimits with Lijevče polje (isohypse of $120 \mathrm{~m}$ height above see level). The mountain system, with its eastern and south-eastern slopes, Banjaluka's Kozara and mountain Piskavica, leans on the left bank of the Vrbas River. From the south mentioned area is framed with peripheral parts of the Prijedorsko polje and alluvial plain of Sana.

At the first level of physiognomic regionalization, Potkozarje is differentiated in the areas of hills and foothills (49\% of the area of region) and the contact zone of the lower slopes with higher peripheral parts of the fields and alluvial plains (51\% of the area of region). Potkozarje is characterized by the upland and lowland area, which is known for gentle slopes and segmentation of the terrain, which is a limiting factor for the development of agriculture and other human activities. Potkozarje is morphostructurally and functionally related to the mountain area of Kozara, which is why the region is, in relation to the environment, predisposed and has advantages for certain forms of mountain tourism. 
Table 1. Potkozarje - general indicators per micro-regions in census for the years 1991 and 2013

\begin{tabular}{|c|c|c|c|c|c|c|c|}
\hline $\begin{array}{l}\text { Micro-regions } \\
\text { Potkozarje }\end{array}$ & $\begin{array}{l}\text { Area } \\
\left(\kappa M^{2}\right)\end{array}$ & $\begin{array}{l}\text { Number } \\
\text { of } \\
\text { residents } \\
\text { year } \\
1991\end{array}$ & $\begin{array}{l}\text { Number } \\
\text { of } \\
\text { residents } \\
\text { year } \\
2013\end{array}$ & $\begin{array}{l}\text { Index } \\
2013 / 91\end{array}$ & $\begin{array}{l}\text { Population } \\
\text { density } \\
\text { (residents } \\
\text { per } \mathrm{km}^{2} \text { ) }\end{array}$ & $\begin{array}{l}\text { Number of } \\
\text { settlements }\end{array}$ & $\begin{array}{l}\text { City (town)/ } \\
\text { municipality }\end{array}$ \\
\hline East & 313,6 & 21950 & 19233 & 87,6 & 61,3 & 16 & Banjaluka \\
\hline Northeast & 454,3 & 17400 & 11381 & 65,4 & 25,0 & 30 & Gradiška \\
\hline Nortwest & 497,4 & 13602 & 11271 & 82,8 & 41,6 & 61 & Koz. Dubica \\
\hline West & 244,4 & 31606 & 20681 & 65,4 & 46,1 & 30 & $\begin{array}{l}\text { Kostajnica } \\
\text { Novi Grad }\end{array}$ \\
\hline South & 337,8 & 38283 & 28531 & 74,5 & 84,4 & 31 & Prijedor \\
\hline Total & 1848,3 & 122841 & 91097 & 74,1 & 49,2 & 168 & \\
\hline
\end{tabular}

With regard to the physiognomy of space and development processes, the region has a complex settlement function. In relation to that, Potkozarje can be conditionally differentiated into five micro-regions: Northwest Potkozarje, West Potkozarje, Northeast Potkozarje, East Potkozarje and South Potkozarje, in the gravitational sphere of appropriate influential centers.

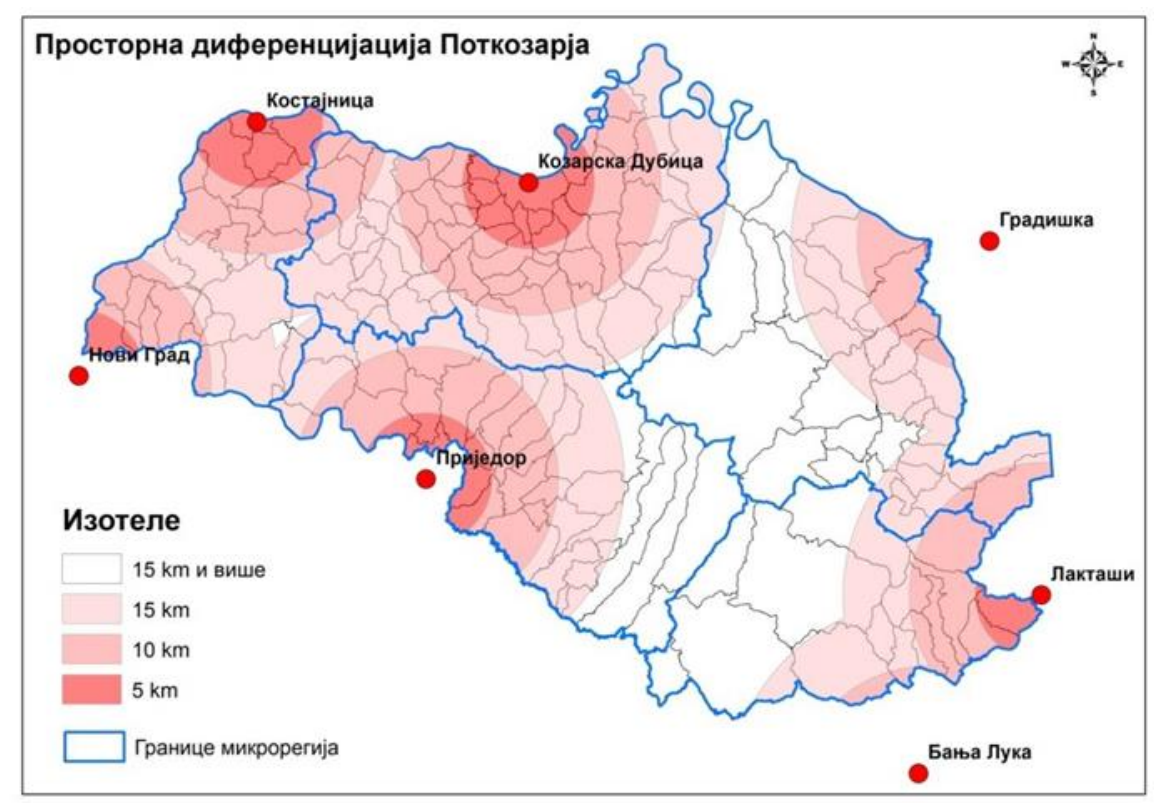

Figure 2. Spatial differentiation of Potkozarje

With modest possibilities of exploitation of natural resources, in the concepts of socialeconomic development, in the socialist period, Potkozarje was on the edge of interest, comparing to other regional units, which disposed with significant mineral and energy potentials. However, significant social-economic changes in the development of region started in 1960s with development of industry, which reflected to the demographic and overall development of the region. Contemporary social-geographic processes are the result of complex political and overall social processes, which in the form of transition marked the development of this region and the Republic of Srpska in general.

In the period of civil war (1992-1995) and the postwar period, social processes, especially political, have a decisive influence on the movement of population in the region and its overall development. 
Today, Potkozarje is a recognizable area that successfully uses its geographic and geostrategic position in the regional and national level, but at the same time it faces with depopulation and problems of restructuring the economy, problems of entrepreneurial activity and attracting new investments.[3]

\section{DEMOGRAPHIC AND SOCIAL-ECONOMIC CHARACTERISTICS}

In the period after the civil war, in Potkozarje, the areas of hills and foothills are characterized by depopulation and deagrarization and modest opportunities for the development of agriculture, particularly of lands. Lowland areas are characterized by low industrialization and urbanization of municipal and local centers and certain problems in valorization of lands.

According to the population census from 2013, the population of region has been reduced by $26 \%$, in comparison with 1991 . Decrease of the total number of the population was followed by decrease of the total number of households, for 3761 or about $11 \%$.

Table 2. Households of Potkozarje, in census for the years 1991 and 2013

\begin{tabular}{|c|c|c|c|c|c|c|c|}
\hline \multirow{3}{*}{$\begin{array}{l}\text { Micro-regions } \\
\text { of } \\
\text { Potkozarje }\end{array}$} & \multicolumn{7}{|c|}{ Households } \\
\hline & \multirow[t]{2}{*}{$\begin{array}{l}\text { Total } \\
1991\end{array}$} & \multirow[t]{2}{*}{$\begin{array}{l}\text { Total } \\
2013\end{array}$} & \multicolumn{3}{|c|}{$\begin{array}{l}\text { According to the number of } \\
\text { members }(\%)\end{array}$} & \multicolumn{2}{|c|}{$\begin{array}{l}\text { According to the type of } \\
\text { settlement }(\%)\end{array}$} \\
\hline & & & 1 & 2 and 3 & $\begin{array}{l}4 \text { and } \\
\text { more }\end{array}$ & central & rural \\
\hline East & 6097 & 6366 & 18.8 & 44.6 & 36.5 & 15.9 & 84.0 \\
\hline Northeast & 5149 & 4005 & 27.2 & 41.3 & 31.3 & 14.8 & 85.1 \\
\hline Northwest & 9502 & 7492 & 25.3 & 45.0 & 29.6 & 47.3 & 52.6 \\
\hline West & 4079 & 4010 & 22.1 & 45.2 & 32.5 & 47.2 & 52.7 \\
\hline South & 10061 & 9254 & 21.6 & 41.0 & 37.3 & 22.3 & 77.6 \\
\hline Total & 34888 & 31127 & 22.7 & 43.3 & 33.9 & 29.3 & 70.6 \\
\hline
\end{tabular}

In the structure of households, in census from 1991, representation of large families (from 3 to 6 members) was $61 \%$. Today, single households and small households (2 and 3 members), represent the most of the households of the region, which is $66 \%$.

Reduction of the multi-member households reflects the social-economic transformation of family households, as a result of demographic processes and the general trends in the organization of social life.

Table 3. Households of Potkozarje, that perform agricultural activities, 2013

\begin{tabular}{lllllll}
\hline & Households & & & \multicolumn{3}{l}{$\begin{array}{l}\text { Households that perform } \\
\text { agricultural activities }\end{array}$} \\
\cline { 2 - 7 } & $\begin{array}{l}\text { Total } \\
\text { city/municipality }\end{array}$ & $\begin{array}{l}\text { Total } \\
\text { local } \\
\text { centers }\end{array}$ & $\begin{array}{l}\text { Other } \\
\text { settlements }\end{array}$ & $\begin{array}{l}\text { In } \\
\text { Potkozarje }\end{array}$ & $\begin{array}{l}\text { Total } \\
\text { city/ } \\
\text { municipality }\end{array}$ & $\begin{array}{l}\text { \% in relation } \\
\text { to } \\
\text { the of } \\
\text { total } \\
\text { households }\end{array}$ \\
\hline Banjaluka & 65010 & 49827 & 15183 & 4234 & 8832 & 13,5 \\
\hline Gradiška & 16939 & 5100 & 11839 & 4005 & 6402 & 37,7 \\
\hline Koz.Dubica & 7492 & 3551 & 3941 & 7492 & 2974 & 39,6 \\
\hline Kostajnica & 1896 & 1174 & 722 & 1896 & 746 & 39,3 \\
\hline Novi Grad & 8792 & 3462 & 5330 & 2114 & 3770 & 42,8 \\
\hline Prijedor & 27961 & 10254 & 17707 & 9254 & 8920 & 31,9 \\
\hline Laktaši & 11293 & 1840 & 9453 & 2132 & 3882 & 34,3 \\
\hline Total & $\mathbf{1 3 9 3 8 3}$ & $\mathbf{7 5 2 0 8}$ & $\mathbf{6 4 1 7 5}$ & $\mathbf{3 1 ~ 1 2 7}$ & $\mathbf{3 5 ~ 5 2 6}$ & $\mathbf{2 5 , 4}$ \\
\hline
\end{tabular}


Number of rural households in the region, according to the census from 2013, which amounts $70,6 \%$, is larger than the number of households in central settlements $29,3 \%$, which indicates a weak industrialization, urbanization and general development of the region.

\section{CONTEMPORARY FUNCTIONS OF CENTRAL SETTLEMENTS OF POTKOZARJE}

Contemporary functions of central settlements and individuallity are determined by the contemporary social-economic trends in the socialist period, and the new values of trafficgeographical position, in which Kozarska Dubica stands out as leading settlement of the region by its physiognomic characteristics and functions.

In contemporary functional organization, in the socialist period, certain central settlements remain without specific functions, which reflects to their total development. That applies to Kozarac, Omarska, Ivanjska and Bosanska Kostajnica. In postwar period (1992-1995), only Kostajnica as central settlement gets confiscated functions.

Contemporary differences in physiognomic characteristics and functions point out the importance of some central settlements in the historical eras. In that sense, according to the level of development, after Kozarska Dubica there are Kostajnica, Omarska, Kozarac, Potkozarje and Gornji Podgradci.

Development of central settlements of Potkozarje in a large extent relies on agriculture and forestry. Complex valorization of the above potentials can have a significant role in the future development of the central settlements and in the overall development of the region.

In the following considerations the functional development of the central settlements of Potkozarje is presented. In fact, it was presumed that the degree of functional development of a particular center is directly implicated: by spatial distribution of the population and by development of functional structure (degree of development of central functions).

Table 4. Central settlements of Potkozarje, according to the degree of development of the basic functions, assessment for the year 2011

\begin{tabular}{|c|c|c|c|c|c|c|}
\hline \multirow{2}{*}{$\begin{array}{l}\text { Micro- } \\
\text { regions } \\
\text { of Potkozarje }\end{array}$} & \multirow[b]{2}{*}{$\begin{array}{l}\text { Central } \\
\text { settlements }\end{array}$} & \multirow{2}{*}{$\begin{array}{l}\text { No. of } \\
\text { Residents } \\
\text { (c.settlement } \\
\text { s) }\end{array}$} & \multicolumn{4}{|c|}{ Functions and their hierarchical relationship } \\
\hline & & & $\begin{array}{l}\text { Administr } \\
\text { ative }^{1}\end{array}$ & ${ }_{2}^{\text {Educational }}$ & Trade $^{3}$ & Productional $^{4}$ \\
\hline $\mathrm{W}$ & Kostajnica & 3561 & $\mathrm{~A}_{2}$ & $\mathrm{~B}_{2}$ & $\mathrm{C}_{1}$ & $\mathrm{D}_{1}$ \\
\hline \multirow{2}{*}{$\mathrm{S}$} & Kozarac & 2585 & $\mathrm{~A}_{3}$ & $\mathrm{~B}_{3}$ & $\mathrm{C}_{2}$ & $\mathrm{D}_{2}$ \\
\hline & Omarska & 3006 & $\mathrm{~A}_{3}$ & $\mathrm{~B}_{3}$ & $\mathrm{C}_{1}$ & $\mathrm{D}_{2}$ \\
\hline $\mathrm{NE}$ & G.Podgradci & 1656 & $\mathrm{~A}_{3}$ & $\mathrm{~B}_{3}$ & $\mathrm{C}_{2}$ & $\mathrm{D}_{2}$ \\
\hline NW & Koz.Dubica & 10005 & $\mathrm{~A}_{2}$ & $\mathrm{~B}_{2}$ & $\mathrm{C}_{1}$ & $\mathrm{D}_{1}$ \\
\hline $\mathrm{E}$ & Potkozarje & 2965 & $\mathrm{~A}_{3}$ & $\mathrm{~B}_{3}$ & $\mathrm{C}_{3}$ & - \\
\hline \multicolumn{7}{|c|}{$\begin{array}{l}{ }^{1} \text { Administrative function (regional center } \mathrm{A}_{1} \text {, municipal center } \mathrm{A}_{2} \text {, local community } \mathrm{A}_{3} \text { ) } \\
{ }^{2} \text { Educational function (faculty } \mathrm{B}_{1} \text {, secondary school } \mathrm{B}_{2} \text {, primary school } \mathrm{B}_{3} \text { ) } \\
{ }^{3} \text { Trade function (shopping centers } \mathrm{C}_{1} \text {, more specialized stores } \mathrm{C}_{2} \text {, grocery store } \mathrm{C}_{3} \text { ) }\end{array}$} \\
\hline
\end{tabular}

Data ilustrated in the previous table show that Kozarska Dubica, in the north-west part of the region, has productional function and other functions of tertiary activities, due to which it is at the leading position in the hierarchy of central settlements. However, 
considering the position in the mountain system of Kozara and trends in social-economic development, mentioned settlement has not developed the functions in education, healthcare and culture, that would meet the needs of the region's population.

Among the other central settlements of the region, only Kostajnica performs the function of the municipal center, and in a hierarchical series of settlements comes right after Kozarska Dubica. Its development and function in the future will greatly depend on the diversification of economic function and entrepreneurial activities.

The following table shows the changes in population trends in development centers, in environment.

Table 5. Population trends in development centers in the region and settlements of Potkozarje, in census for the years 1991 and 2013

\begin{tabular}{lllll}
\hline & \multicolumn{2}{c}{ Population movement } & & \\
\cline { 2 - 5 } Development centers & \multicolumn{3}{c}{ 1991 } & \multicolumn{2}{c}{ In settlements } \\
\cline { 2 - 5 } & in centers & $\begin{array}{l}\text { of } \\
\text { Potkozarje }\end{array}$ & In centers & $\begin{array}{l}\text { In } \\
\text { settlements } \\
\text { of Potkozarje }\end{array}$ \\
\cline { 2 - 5 } & 143079 & 5326 & 180053 & 8903 \\
\hline Banjaluka & 3483 & 16624 & 34210 & 10330 \\
\hline Laktaši & 16841 & 17400 & 49196 & 11381 \\
\hline Gradiška & 13588 & 8800 & 25240 & 5626 \\
\hline Novi Grad & 34635 & 38283 & 80916 & 28531 \\
\hline Prijedor & & & & Source: [4], [7]
\end{tabular}

In the formation of development centers in the region and its urban character, there are commercial-craft and social-political functions. These functions remain important for these settlements until today.

Observing the population trends, development of functions and especially pronounced tendencies of completion of functions, Banjaluka stands out in the group of development centers in the area of Potkozarje, by the overall level of development.

According to the development of functions and extent of the impact, this development center has the characteristics of a regional urban center for the entire region of Potkozarje and wider.

The smaller degree of development of functions and limited impacts on its immediate surroundings have other development centers Laktaši, Gradiška, Prijedor, Novi Grad, which do not have a pronounced effect on the entire region.

In determining the functional characteristics of development centers in the region, the structure of employees per sectors of activity was shown.

Table 6. The structure of employees per sectors of activity in (\%), in development centers in the area of Potkozarje, situation in the year 2015

\begin{tabular}{llllll}
\hline Activity & Banjaluka & Laktaši & Novi Grad & Prijedor & Gradiška \\
\hline Agriculture & 0,8 & 3,3 & 2,0 & 1,9 & 4,8 \\
\hline Industry & 12,7 & 29,9 & 14,6 & 18,6 & 27,2 \\
\hline Civil Engineering & 4,8 & 10,3 & 0,6 & 3,5 & 2,5 \\
\hline Traffic & 3,5 & 5,2 & 12,8 & 4,6 & 5,1 \\
\hline Trade and catering & 22,6 & 32,2 & 30,3 & 24,3 & 24,2 \\
\hline Education & 7,9 & 4,1 & 11,7 & 10,3 & 9,4 \\
\hline Social activities & 47,7 & 15,0 & 28,1 & 36,8 & 26,8 \\
\hline & & & & Source: [6]
\end{tabular}


The general overview of the structure of employed population according to sectors of activity, in 2015, points to the fact of pronounced differentiation in the structure of employees by the activities and in relation to that, differentiation in the functions (e.g. at industry with the largest share in the structure of employees in Laktaši $29,9 \%$, and up to $12,7 \%$ in Banjaluka in social activities in Prijedor 36,8\%, and up to 15,0\% in Laktaši).

Banjaluka, Laktaši and Gradiška have a higher value of traffic-geographical position in relation to the areas in their environment. Their transit functions are conditioned by privileged traffic directions, where the functions of interregional and interstate cooperation come to the fore, which is precondition for better spatial and functional integration and development. [2]

\section{SOME SIGNIFICANT PROBLEMS OF DEVELOPMENT OF RURAL SETTLEMENTS OF POTKOZARJE}

Social-economic processes in the socialist period constantly influenced the emigration of the population and loss of function of rural areas. Process of emigration conditioned strong depopulation of hill and foothill areas and deagrarization. In the process of industrialization, the rural areas of Potkozarje remained isolated and with underdeveloped infrastructure. Lack of appropriate development strategies and lack of social care have resulted in the lagging of development of villages and rural areas and deepening of internal regional diversities.

With functional underdevelopment, central settlements of Potkozarje have not been able to keep the young and working age population. With the departure of the working age population, the share of the elderly population in rural areas increased at the expense of young and mature.

In census from the year 2013, population of Potkozarje shows a tendency of aging, in comparison with 1991.

Table 7. The age structure of population of Potkozarje, according to the census from 1991 and 2013.

\begin{tabular}{|c|c|c|c|c|c|c|}
\hline \multirow{2}{*}{$\begin{array}{l}\text { Micro-regions of } \\
\text { Potkozarje }\end{array}$} & \multicolumn{3}{|l|}{1991} & \multicolumn{3}{|l|}{2013} \\
\hline & $0-19$ & $20-59$ & $\begin{array}{ll}60 & \text { and } \\
\text { more }\end{array}$ & $0-19$ & $20-59$ & 60 and more \\
\hline East & 28,6 & 54,9 & 16,4 & 24,7 & 55,6 & 19,5 \\
\hline North east & 24,2 & 52,8 & 22,8 & 18,0 & 52,2 & 19,0 \\
\hline West & 24,2 & 54,9 & 20,8 & 18,0 & 57,1 & 24,7 \\
\hline North west & 22,5 & 54,7 & 22,7 & 17,4 & 54,8 & 27,6 \\
\hline South & 34,6 & 51,2 & 14,0 & 18,7 & 56,7 & 24,5 \\
\hline
\end{tabular}

In the census in 2013, it is recorded an overall decrease of the population in the region by $26 \%$, and in central settlements by $31,4 \%$.

Low industrialization and urbanization of central settlements only partially mitigated the intensity of emigration and functional destruction of the region. 
Table 8. Settlements of Potkozarje by the size categories, according to the census from 1991 and 2013

\begin{tabular}{|c|c|c|c|c|c|c|}
\hline & 1991 & & & 2013 & & \\
\hline Size group & $\begin{array}{l}\text { Number of } \\
\text { residents }\end{array}$ & $\begin{array}{l}\text { Numb } \\
\text { er of } \\
\text { settle } \\
\text { ments }\end{array}$ & $\begin{array}{l}\% \text { of the total } \\
\text { number of } \\
\text { residents }\end{array}$ & $\begin{array}{l}\text { Number of } \\
\text { residents }\end{array}$ & $\begin{array}{l}\text { Numb } \\
\text { er of } \\
\text { settlem } \\
\text { ents }\end{array}$ & $\begin{array}{l}\% \text { of the total } \\
\text { number of } \\
\text { residents }\end{array}$ \\
\hline From 100 & 1276 & 19 & 1,0 & 3142 & 46 & 3,4 \\
\hline From 101 to 500 & 23875 & 93 & 19,4 & 18883 & 77 & 20,7 \\
\hline From 501 to 1000 & 19007 & 28 & 15,4 & 15166 & 21 & 16,6 \\
\hline From 1001 to 2000 & 27432 & 20 & 22,3 & 15411 & 12 & 16,9 \\
\hline From 2001 to 5000 & 51251 & 8 & 41,7 & 38495 & 12 & 42,2 \\
\hline Total & 122841 & 168 & 100,0 & 91097 & 168 & 100,0 \\
\hline
\end{tabular}

Small settlements have the largest share in Potkozarje (less than 500 residents) 73,2\%, medium size settlements (less than 2000 residents) 19,6\% and large settlements (over 2000 residents) $7,1 \%$. The region is dominated by small settlements with large dispersion, which complicates their traffic connection, maintenance of existing infrastructure and revitalization.

\section{CONCLUSION}

The specificity of the regional system of Potkozarje, it is primarily referred to the demographic and social-economic structures, is in many ways defined by the special circumstances in which this spatial system developed, after World War II. Taking into account these assumptions of the development and influence of the state - former SFRY, its potentials, general, economic and social development, but also the influence of the regional environment and in particular the leading development centers from the region, Potkozarje, in a long period of time was exposed to all destructive processes of general and regional development.

On the other hand, a respectable coverage of the regional system of Potkozarje, but without development and sufficiently developed centers, which would stimulate development, has even more been exposed to the functional impact of the centers from the surroundings. Therefore, system of Potkozarje was day by day becoming more a "system" of smaller, relatively differentiated zones determined by the influence of gravitational range of development centers from the region, and more regional "system" marked only by geographical concept. Characteristic historical periods, particularly socialist, marked by strong industrialization, but also the processes that have left the destructive consequences in some rural areas, as it is Potkozarje in some parts, strongly influenced the shaping of the cultural landscape, as an expression of specific socialeconomic and overall development processes.

General development of Potkozarje, in the period after the civil war, was not significantly changed, in relation to the period up to 1991, there was no construction of local roads and other infrastructure, which would connect rural settlements, in the area of hills and foothills, with the local and municipal centers in the region and its surroundings, which would slow down the destructive processes in the region.

Mulching of households and unplaned construction also affect the overall territorial organization of the settlement system. Central settlements with their spatial expansions, in the border area of the region in surroundings of development centers Banjaluka, Laktaši 
and Prijedor cause sequel, but also additional problems in the valuation of agricultural space.

Reduce in the number of the region's population also causes certain problems in the spatial distribution of social infrastructure (schools, ambulances, post office) and its survival.

In spatial expansion of central settlements it is important to emphasize the necessary social care for the protection of agricultural land, because on the basis of morphophysionomical features of Potkozarje, agrarian function makes the perspective of the region.

Potkozarje has a tradition in the development of balneological tourism and, in accordance with its position in the mountain system of Kozara, significant transit function in the development of tourism of the mountain area. Therefore, it is realistic to expect that the development of tourism in the mountain area of Kozara will affect other functions of the central settlements in the region, specially those with transit role.

\section{REFERENCES}

[1] Tosic, D. The principles of regionalization. University of Belgrade. Faculty of Geography. pp 25-30, 2012.

[2] Mislicki Tomic, T., Petrasevic, A: Regional polarization of the cities of the Republika of Srpska and the International Scientific Conference. "Center-periphery" systems in the context of globalization and regionalization: theory and practice of social and geographical research, Simferopol, Russian Federation pp. 311-319, 2015.

[3] Strategic plan for the development of agriculture and rural areas of the Republic of Srpska 2016-2020, University of Banja Luka, Faculty of Agriculture, Banja Luka, 2015

[4] Population Census 1991, the population Bosnia and Herzegovina, Population composition by settlements, Bureau of Statistics of the Republic of Croatia, Zagreb, 1995.

[5] Census of population, households, flats and agricultural holdings 1991, Households by populated places, Federal Bureau of Statistics Bosnia and Herzegovina, Sarajevo, 1999.

[6] Statistical Yearbook of the Republic of Srpska (II revised edition), Overview by municipalities and cities, Employees by areas of KD in 2015, Bureau of Statistics of RS , 2016.

[7] Census results 2013, Population by age and gender by age five, Towns, settlements, Bureau of Statistics of RS, Banja Luka, 2017

[8] Results of the 2013 Census, Households by number of members, Populated places, Bureau of Statistics of RS, Banja Luka, 2017.

[9] Results of the 2013 Census, Households performing agricultural activity, Towns / Municipalities, Bureau of Statistics of RS, 2017., Banja Luka, 2017 